Article

\title{
Is the Grass Greener on the Other Side? Norwegians' Assessments of Brexit
}

\author{
John Erik Fossum * and Joachim Vigrestad \\ ARENA, University of Oslo, 0318 Oslo, Norway; E-Mails: j.e.fossum@arena.uio.no (J.E.F.), \\ joachim.vigrestad@arena.uio.no (J.V.) \\ * Corresponding author
}

Submitted: 2 October 2020 | Accepted: 27 December 2020 | Published: 27 January 2021

\begin{abstract}
To what extent has Brexit affected Norwegians' perceptions of their current relationship with the EU? What are the considerations that central political and societal actors bring up to explain their stances? What are the broader lessons for the EU's relations with non-members? We argue that Norway's EU affiliation is so close that we can draw on Catherine De Vries' benchmark theory to assess whether Brexit affects Norwegians' assessments of Norway's relationship with the EU. We focus on the Norwegian government's stance. Further, we consider opinion polls to understand the strength of domestic support for the EEA Agreement, and whether that support has changed as a consequence of Brexit. We thereafter look for political entrepreneurs or political change agents, in political parties, in interest groups, and among civil society activists. We find that Brexit has not served as a benchmark. It has not set in motion efforts to change Norway's EU affiliation. Opponents diverge on alternatives, although share concerns about what they see as the EU's neoliberal orientation. The analysis shows that we cannot assess Brexit as a benchmark without paying attention to the sheer size and magnitude of the EU-Norway power asymmetry.
\end{abstract}

\section{Keywords}

benchmark theory; Brexit; EEA Agreement; European Union; Norway

\section{Issue}

This article is part of the issue "What Brexit Means for Europe: EU Institutions and Actors after the British Referendum" edited by Edoardo Bressanelli (Sant'Anna School of Advanced Studies, Italy) and Nicola Chelotti (Loughborough University London, UK).

(C) 2021 by the authors; licensee Cogitatio (Lisbon, Portugal). This article is licensed under a Creative Commons Attribution 4.0 International License (CC BY).

\section{Introduction}

The EU has developed a comprehensive system of affiliations with neighboring states. The system of EU affiliations has bearings on the process and outcome of Brexit, given that it represents templates for how the UK and the EU may organize their relations post-Brexit. Conversely, these affiliations can be affected by the UK's exit from the EU. That is what we consider here with explicit reference to Norway. This article addresses the following questions: To what extent has Brexit affected Norwegians' perceptions of their current relationship with the EU? What are the considerations that central political and societal actors bring up to explain their stances? What are the broader lessons for the EU's relations with non-members? We examine the views of a wide range of Norwegian actors in order to establish whether they have Brexit-related rationales for altering Norway's relationship with the EU. The assessment of whether the UK's decision to leave the EU has affected Norwegians' views of their current EU affiliation will provide us with important insights into the robustness of the EU's present arrangements with non-members, what is often referred to as the pattern of EU external differentiation ("externalization of the acquis communitaire"; Leuffen, Rittberger, \& Schimmelfennig, 2013, p. 17).

There are several reasons for paying special attention to Norway. For one, Norway's EU affiliation, through 
the European Economic Area Agreement (EEA) and a host of other agreements, places Norway among the EU's most closely affiliated non-members. Norway is one among few affiliated non-members that qualifies for EU membership (Eriksen \& Fossum, 2015). That is important for comparability with the UK, which through its well over four decades of EU membership is thoroughly Europeanized. Further, the EU's aim was initially to establish an agreement with the UK that was as similar to Norway's EEA affiliation as possible, not the least because the EEA Agreement has formed the template for the EU's relations with its most closely associated non-members (Gstöhl \& Phinnemore, 2019).

The UK, on its part, has rejected the type of single market participation and membership in the EU's Customs Union that the EEA Agreement implies. After long and protracted negotiations, the EU-UK Trade and Cooperation Agreement was signed on December 24, 2020. Nevertheless, transitory elements, implementation reviews and openings for further multilateral and bilateral cooperation leave quite a bit of fluidity. It is therefore questionable whether what we know at present provides us with sufficiently stable markers to tell us what form of privileged partnership the UK will end up with.

What we at present can investigate is whether the example of Brexit has affected members' and affiliated countries' assessments of their present EU relationship. For sovereigntists across Europe, Brexit and the mantra of 'taking back control' offers the prospect of escaping from the shackles of the EU. At the same time, the UK's complicated process of exiting from the EU shows how profoundly EU member states have been incorporated in the EU-led European political and economic order, not only vertically but also horizontally through tight bonds and interdependencies between states and societies across Europe.

In the following, we start by spelling out the analytical framework. It draws on Catherine De Vries' (2017, 2018) benchmark theory. Her application of this theory to Brexit posits that people compare the costs and benefits of their current EU affiliation with alternative statuses (of non-membership). In applying the benchmark theory to Norway, we must identify the actors that refer to Brexit as a template for Norway's future EU affiliation and the aspects-issues and concerns-they base their evaluations on. The next section outlines the distinctive features of Norway's EU affiliation in order to clarify the nature of the status quo, which is necessary for understanding what Norwegians assess Brexit against. The subsequent section considers the actors' stances. We start with the Norwegian government, thereafter consider opinion polls to understand the strength of domestic support for the EEA Agreement, and whether the level of support has changed as a consequence of Brexit. After that, we look for political entrepreneurs or political change agents in political parties, interest groups, and among civil society activists, notably the sig- nificant No to the EU organization. In the final concluding section, we discern broader lessons from this case study for the EU's relations with affiliated non-members.

\section{Brexit and Benchmark Theory}

There was quite a bit of concern after the Brexit vote in 2016 that the UK's example would encourage other member states to exit the EU. That has not materialized in the EU's member states. Instead of fragmentation, the EU's response to Brexit thus far has been, to cite Brigid Laffan (2020), "rapid, united and effective." In this article, our concern is whether we see similar patterns of preserving the status quo in closely affiliated non-member states. If we look at the case of Switzerland, we see that the EU has been concerned with preventing Brexit from having spillover effects. Swiss voters in a recent referendum appear to have recognized this by rejecting a proposal that would have torn up Switzerland's free movement agreement with the EU (Jones, 2020).

Do we see similar patterns in Norwegians' evaluations of their EU affiliation? In order to address this, and to draw broader lessons for the EU's relations with affiliated non-members, we need to identify not only change agents, but also the factors that key veto players (such as governments) hold up as decisive for their stances. That means that we need a theoretical framework that says something about actors' reasoning when confronted with what some see as a threat to stability and others see as an opportunity for change or transformation. The benchmark theory offers precisely such a theory.

According to the benchmark theory:

People's attitudes towards Europe are ultimately rooted in a comparison, namely a comparison between the benefits of the current status quo of membership with those associated with an alternative state of one's country being outside the EU. The decision of the British to leave the EU provides people with valuable information about the possible economic and political costs and benefits associated with the alternative state. (De Vries, 2017, pp. 40-41)

The benchmark theory builds on the notion that citizens' levels of EU support depend on their perception of national political and economic performance. Brexit provides an opportunity to extend that to a comparison across national contexts. Prior to Brexit, such comparisons had to be based on counterfactuals-and all the uncertainty associated with using such as benchmarksgiven the lack of real-life examples of states exiting the EU.

When the UK exited from the EU and became the first ex-member state (Lord, 2015), it replaced the counterfactual with a real-life example. The tangled Brexit process exhibits the dilemmas, choices and conflicts involved in exiting from the EU in today's interdepen- 
dent world. The benchmark theory posits that actors calculate utility (costs and benefits) as well as relate to risk and uncertainty. We posit that the more uncertainty there is about the UK's future EU affiliation, the more difficult it is for actors to calculate utility. Uncertainty brings up power relations and patterns of asymmetrical interdependence.

In applying the benchmark theory to closely affiliated non-members such as Norway, we need to keep in mind that "the transaction costs associated with leaving are different from those of not joining" (De Vries, 2017, p. 41). We recognize this and therefore adopt the reverse approach: We consider whether the UK's departure from the EU has served as a benchmark for how Norwegians assess their EU affiliation. We argue that this comparison is valid, given that we clarify an important issue about sovereignty with bearing on comparability. Brexit is about restoring UK sovereignty, whereas Norway through the EEA Agreement and its other agreements with the EU has not formally rescinded sovereignty to the EU. This difference can affect application of the benchmark theory to Norway. One issue is whether formal retention of sovereignty is matched by real-life or lived experience; the other is whether the issue of sovereignty affects Norwegians' perceptions of their own country's performance.

On the former, Norway's EU affiliation is so close and committing that there is a gap between formal sovereignty and actual autonomy. Our starting assumption builds on that: The more closely affiliated the non-member is to the EU-the fewer differences there are between the lived reality of the EU member and the non-member-the more relevant for Norway are De Vries' findings from applying the benchmark theory to EU member states.

On the latter, the discrepancy between formal sovereignty and actual autonomy sets Norway apart from EU member states and has bearings on how Norwegians assess their EU affiliation. On the one hand, the gap between formal sovereignty and actual autonomy can trigger pleas for action to align reality with formal status. On the other hand, key political actors who are concerned with retaining Norway's close EU affiliation attach great importance to keeping the controversial sovereignty issue off the political agenda. For Norway, both the question of sovereignty and EU membership can serve as a 'benchmark trigger.' There are actors that are interested in pursuing alternatives to the present EU affiliation, regardless of Brexit.

De Vries presents three sets of findings that we discuss in relation to Norway. First is that Brexit brings up uncertainties surrounding the UK's role and status post-Brexit, which prompt EU members to favor the status quo. As we explicate below, we expect a similar effect in Norway due to the high level of asymmetrical political and economic interdependence and the close ties that bind Norway to the EU. Non-membership forms of affiliation are precarious, especially under conditions of rapid contextual changes. We thus expect support for the status quo to be especially strong with regard to the Norwegian government. Norway's EU affiliation adds to that. It is a political compromise that has been deliberately depoliticized. We expect the government to be particularly concerned about the need for minimizing risks and disruptions.

De Vries' second finding is that Brexit appears to increase public support for EU membership. Translated to Norway our second assumption is that Brexit will favor the status quo, by increasing support for the EEA Agreement as the main and most visible plank of Norway's EU affiliation.

A third effect that De Vries presents is the rise of Eurosceptic populist political entrepreneurs that do not share the government's assessment of the risks associated with altering the status quo, and therefore seek to change it. Our third assumption is that we expect a similar development in Norway given that Norwegian EU membership remains a contested issue.

What then are the cost-benefit and risk assessments that Norwegians apply? As noted above, the more uncertainty there is surrounding the UK's future EU relationship, the less reliable the utility calculations, and the more actors' assessments will focus on reducing uncertainty. Norway's EU affiliation is a precarious attempt at reconciling sovereignty retention with access to the EU's single market and EU programs. Thus, we expect the actors to be well-aware of the political and economic costs and risks of changing the status quo and for this to figure as a central theme in their assessments. Governments share with business communities an onus on stable and predictable rules and terms of operation, not only in the economic but in the political realm.

Risk and uncertainty are bound up with power and hegemony. Closely affiliated non-members are aware of the asymmetrical nature of their EU affiliation, which suggests that they may be concerned with the possible fall-outs of perhaps even fairly unsubstantial changes. EU members have access to decision-making forums where they can renegotiate the terms of their affiliation through opt-outs and derogations, etc. For non-members, there is no similar access, and as we noted above with reference to Switzerland, non-members are concerned that efforts to change aspects of an affiliation may put the affiliation at risk. There is for instance a 'guillotine clause' in the Schengen agreement so that deviations or non-compliance entail that the entire agreement unravels. Norway has also for instance never actually used the EEA Agreement's right of reservation (Article 102) that allows a party to opt-out of a piece of legislation without blocking the entire legislation. The implication is that power and the significant asymmetry in Norway-EU relations matter to Norwegian actors' assessments of the balance of risk versus utility of a given mode of affiliation.

For many Norwegians, factors affecting their views of the EU and what they look for in relation to Brexit 
are issues related to the welfare state, immigration, economic regulations and social regulations, and gender equality. These are long-lasting concerns that have affected people's views of the EU (as was readily apparent in the 1994 EU referendum). They straddle the line between specific policies and the broader outlines of a model of social economy that is environmentally sustainable. The EU has underlined the need to sustain its understanding of social market economy and environmental sustainability (European Commission, 2017). Whether Norwegians align with the EU's stance or not, we expect Norwegians to be concerned as to where the UK post-Brexit locates itself on the issues of market intervention, social justice and environmental sustainability. Norwegians clearly follow the Brexit process with great interest (Haugevik, 2017), even if they may not consider it a case to emulate.

\section{Outlining the Status Quo: Overview of Norway's Current EU Affiliation}

Before analyzing how the various types of actors in Norway see Brexit as a possible spur to reconsider Norway's EU affiliation, we need to look more closely at this affiliation and especially the thorny issue of sovereignty. We start by presenting in broad outlines the nature of this affiliation, and thereafter look more closely at the politics surrounding it.

Norway signed the EEA Agreement with the EU before the 1994 EU membership referendum. Today, Norway's EU affiliation consists in more than 70 agreements, ranging from the internal market, Schengen association agreements, agreements on asylum and police cooperation (Dublin I, II and III), agreements on foreign and security policy (Norway participates in the EU's battle groups), and agreements on internal security and justice cooperation. Through these agreements, Norway has incorporated roughly three-quarters of EU legislation compared to those EU member states that have incorporated everything (Official Norwegian Reports, 2012). In effect, Norway's approach has been to seek as close an EU association as is possible for a non-member. Assessed in terms of per capita, Norway's contribution is less than two-thirds of the UK's ( $f 140$ per person in Norway and f220 per person in the UK).

Institutionally speaking, the EEA Agreement is based on a two-pillar structure with bridging arrangements between EFTA and the EU, a court, and a surveillance body, the European Surveillance Authority (see EFTA, 2017). The two-pillar structure was understood as the only possible solution that would retain an intergovernmental agreement without supranational characteristics (Børde, 1997, p. 111). The EEA-EFTA states were not willing to rescind sovereignty to a set of international institutions.

Nevertheless, in actual practice these states are profoundly affected by the EU. Within the EEA-EFTA states, the EU's legislation - in contrast to the situation in the member states - is not formally anchored in the legal precepts of supremacy and direct effect. The reality is, however, not as different as the formal structure would suggest (Egeberg \& Trondal, 1999; Eriksen \& Fossum, 2015). As Gänzle and Henökl (2017) note, the relationship is close to 'quasi membership.'

In the member states, EU law trumps national law in those issue-areas where the EU has been conferred competence, whereas in Norway, the European Surveillance Authority ensures that legal incorporation is in accordance with EU law, and the EFTA Court in practice ensures the incorporation of EU law. This relationship is clearly one-way; Norwegian citizens are pure recipients of decisions made outside of Norway. There is no form of reciprocity or 'export' of Norwegian decisions to the EU.

This dense and dynamic model of affiliation has important bearings on Norway's ability to retain its socioeconomic model, which has historically speaking been marked by economic governance, including state support; organized working life; and public welfare services. The EU has especially in the last decade moved in a neoliberal direction, which has been embedded in the manner in which it promotes the four freedoms: persons, capital, goods and services. Norway is a heavily Europeanized country, and is therefore feeling the full effects of these developments. It should however be added that Norway has compensatory arrangements and a strong fiscal buffer; thus has domestic leverage to protect the most vulnerable groups and persons from market and other contingencies (Fossum \& Graver, 2018).

Norway's EU affiliation is touted as a compromise. It must be viewed in light of the fact that Norway has applied for EU membership four times. The two first, in 1962 and 1967 were aborted due to de Gaulle's veto against the UK's application. The two latter, submitted in 1970 and 1992, saw small majorities of the population rejecting EU membership in popular referenda (in 1972, $53.5 \%$ against and $46.5 \%$ for, and in 1994 52.2\% against, and $47.8 \%$ for).

What is important to underline is that the political dimension of Norway's EU affiliation is marked by a paradox: The question of EU membership remains a very contentious issue, and yet, Norway's close and dynamic EU affiliation has sparked very little political controversy (Official Norwegian Reports, 2012). The main reason is that Norwegian governing coalitions and the party system have successfully de-coupled the controversy surrounding the EU membership issue from the ongoing process of EU adaptation.

The political mobilizations and the very high referendum participation rates $(79.2 \%$ in 1972 and as high as $89 \%$ in 1994; Statistics Norway, 1995) show how divisive the issue of Norwegian EU membership has been. This question has figured as one of, if not, the, most politically divisive issues in Norway, at least since the Second World War. The EU membership issue reawakened or gave added impetus to old and entrenched cleavages, such as center against periphery, region against region, 
rural against urban areas, and deep divisions within and between political parties. The main difference between 1972 and 1994 was that defense of the welfare state, the public sector and gender equality became more important reasons for rejecting EU membership.

To avoid destructive political battles, political actors have for a long time taken measures to de-politicize the contentious EU membership issue; hence keeping the contentious issue of sovereignty off the political agenda. Norwegian parties operate with a set of gag rules to keep the issue of EU membership off the political agenda (Fossum, 2019). Norway's proportional electoral system makes it very difficult for a single party to gain a majority; hence parties enter into coalitions. Every coalition constellation since 1994 has consisted of parties that variously support EU membership and oppose it. All of these coalition agreements are based on the notion that a political party that seeks to alter the status quo-actively seeking EU membership or revoking the EEA Agreement-will violate the coalition agreement. No governing party has therefore actively worked to alter the status quo.

By removing the most contentious issue of constitutional and political sovereignty from the political agenda, this arrangement makes rapid and dynamic EU adaptation possible. That explains the paradox listed above. The effect is for conflict and disagreement to shift away from the contentious normative questions about constitutional and political sovereignty and onto single issues, which can be treated as isolated incidents.

A governing party that tries to undo the status quo thus faces significant political risks, in that the coalition may unravel. It is difficult to understand these political constellations and forms of self-bind without taking into account the significant asymmetry in power relations between the EU and Norway.

In the following, we consider what aspects of Norway's EU relationship Brexit may set in motion, and do so across a wide range of different actors. Our main approach is to look for explicit references to Brexit; we do not include change proposals or pleas for change that do not make this connection explicitly. Brexit can trigger action to reinforce Norway's existing EU affiliation, either through a closer engagement with the EU or through initiating an EU membership process.

If we look at the different positions that have been proposed in the debate on Norway's EU affiliation over time, we find the following options: 1) Abolish the EEA Agreement and negotiate a free trade agreement with the EU; 2) renegotiate the EEA Agreement; 3) renegotiate Schengen (with or without changes to the EEA); 4) apply for EU membership. Brexit could trigger initiatives along all of these.

\section{The Positions of the Norwegian Actors}

The previous section showed how closely affiliated Norway is with the EU. At the same time, there is no doubt that Brexit is consequential given that the UK is Norway's largest single-state trade partner in goods (Norwegian Government, 2016). Hence, the arrangement that the UK settles with the EU will have direct effects on Norway, since the goods trade is regulated by the EEA Agreement. In the following, we will outline the various actors' positions.

\subsection{The Norwegian Government's Position}

The Norwegian government has, in line with the first expectation we derived from the benchmark theory, consistently defended the status quo by stressing the importance of retaining the EEA Agreement. Foreign Minister Ine M. Eriksen, at a meeting in the Parliament's European Affairs Committee on February 7, 2018, noted that many people appear to think that Norway's relationship to the EU will change with Brexit; she rejected this assessment arguing that: "It does not. Our relationship to the EU is there through the EEA Agreement and other agreements, but it is our relationship to Great Britain where we will form other agreements and build other frameworks" (Søreide, 2018a, authors' translation). The government stressed its preference for a 'tidy' and predictable Brexit process and outcome, not a messy process and a no deal outcome. The government is thus not only concerned with retaining the status quo in relation to the EU but wants stable relations with the UK.

The onus on retaining status quo also implies a prioritization of relations. The Foreign Minister noted on October 20, 2018 that:

A position that we share with the $\mathrm{EU}$ is that we are very concerned about the integrity of the internal market, namely that it should not be possible to divide up the four freedoms and as such destroy the internal market...we are concerned about having a very close relationship to the British and a close trading relationship also after Brexit. But we must at the same time be clear that for Norwegian interests it is readily apparent that preservation of the internal market which provides us with common rules of conduct, market access, common standards etc. is immensely important for Norway given that $80 \%$ of our exports go to the EU. That includes the opportunity to bring in labor when we need it. (Søreide, 2018b, authors' translation)

The government that has been in power since 2013 is now a minority coalition government. It is composed of two parties in favor of EU membership, and one party that is against EU membership but in favor of retaining the EEA Agreement. The opposition is also divided but mainly over the EEA issue. The largest party Arbeiderpartiet (Labor) no longer has EU membership as a stated party aim but supports the EEA Agreement. The same do de Grønne (the Greens), whereas Senterpartiet (the Center Party), Fremskrittspartiet (the Progress 
Party), Sosialistist Venstreparti (the Socialist Left Party) and Rødt (Red) all want to renegotiate Norway's EU affiliation in the direction of a less comprehensive arrangement. We will after the next section on public support check the constellation of party positions and whether these have changed in order to get a better sense of the robustness of government support for its status quo line, as well as the arguments and justifications that change-seeking parties present.

\subsection{Changes in Public Support for the EEA Agreement after the UK Referendum?}

As noted above, a key concern of the benchmark theory was to establish whether the uncertainties associated with Brexit led to increased EU support. Figures 1 and 2 show the results of opinion polls on the Norwegian population's views on EU and EEA membership over time. The graphs merge these polls. In those years where several polls have been conducted, we have listed the average of these. For the EEA barometer there are no measures for 2013-2015.

Figure 1 is on support for EEA membership, in other words the status quo, and shows that this has seen a steady rise from $46 \%$ in 2012 to $62 \%$ in 2020 . Opposition to the EEA has fallen from $34 \%$ in 2012 to $25 \%$ in 2020, exposing a widening gap between supporters and opponents of the EEA. If we look at the curves, we see a significant increase in support for the EEA Agreement between 2012 and 2016, but how much of that can be directly attributed to Brexit is not clear, since we lack figures for 2013-2015. Nevertheless, the change between 2012-2016 was reinforced through a steady increase in support for the EEA Agreement after 2016.
With regard to EU membership, we see in Figure 2 that opposition to EU membership was at $74.3 \%$ in 2012 , but has declined to $62.7 \%$ in 2020 , whereas support for EU membership has increased from 16.7\% in 2012 to $28.3 \%$ in 2020.

We thus see that the pattern of support is consistent with the second assumption of the benchmark theory, namely that when translated to Norway Brexit will increase support for the status quo or the EEA Agreement. Since the pollsters did not include any questions about Brexit, we do not know how significant Brexit was in prompting these changes.

We can however approach the question of correlation indirectly by querying to what extent important opinion-makers such as political parties, political advocacy organizations and other politically relevant actors, such as employers' and employees' organizations advocated changes versus defended the status quo. The balance of status quo defenders and political change entrepreneurs will give us additional information on the factors and forces driving the patterns of public opinion that we observe.

\subsection{Actors Debating or Initiating Changes to Norway's EU Relationship}

The strong and rising support for the EEA Agreement in public opinion polls may reflect a positive endorsement of the agreement, or it may reflect a lack of viable options. It has long been the mantra of governing parties that there is no alternative to the EEA Agreement if we want to have assured market access to our closest neighbors and trading partners. Opponents are therefore put under pressure to come up with viable alternatives, and

70

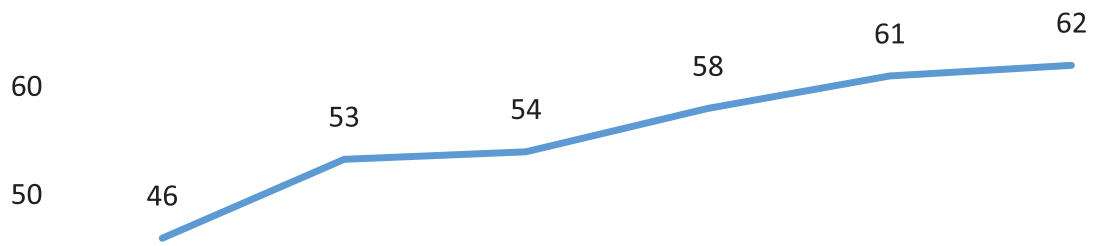

40

30

34

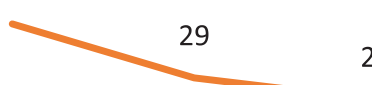

\section{7}

20

18

19

24
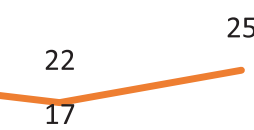

25

13

10

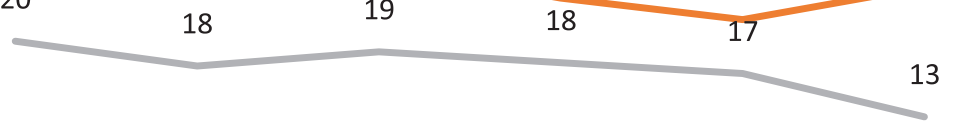

$\begin{array}{llllll}2012 & 2016 & 2017 & 2018 & 2019\end{array}$

Figure 1. EEA barometer. Source: Sentio (2020). 
80

74,3

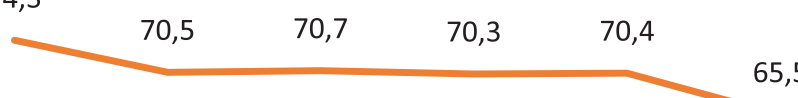

$65,5 \quad 65,9$

60

50

40

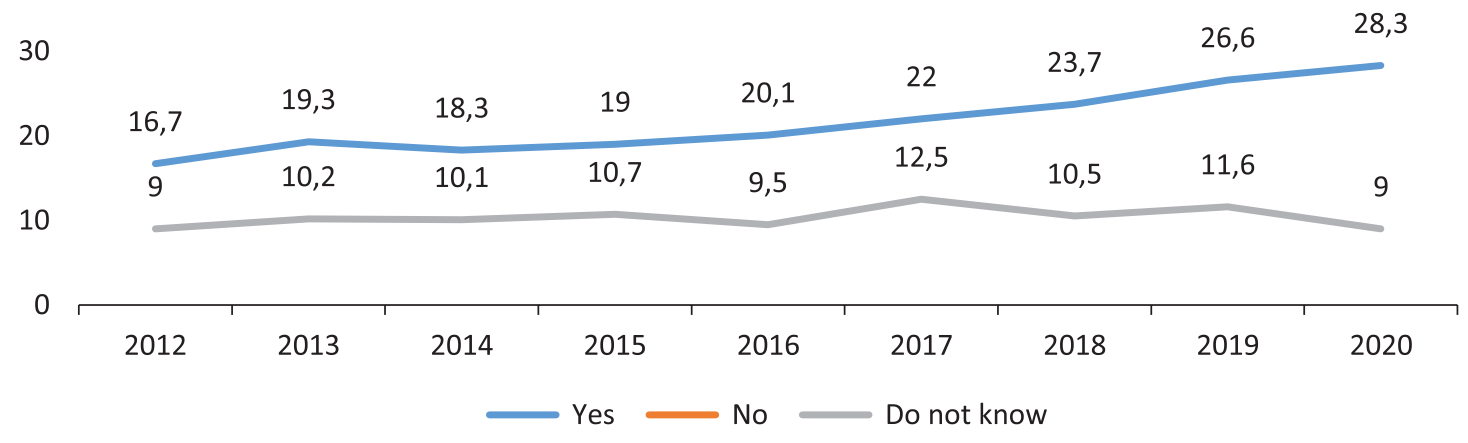

Figure 2. EU barometer. Source: Sentio (2020).

some actors, as we will show, refer to Brexit as the vehicle to open up the door to such alternatives.

\subsubsection{Political Parties}

With regard to political parties, we focus only on those instances where party programs or officials make explicit references to Brexit as the motivation for the change proposal. We have examined the party programs for all political parties from 2013 to the present. In addition, we have examined parliamentary plenary debates as well as debates in the Norwegian Parliament's European Affairs Committee from the time of Brexit and up until today in search of information on how MPs think Brexit will affect Norway's EU relationship.

The following party programs mention Brexit explicitly, Red, a party with Marxist-Leninist roots, which got $2.4 \%$ in the 2017 parliamentary election; the environmental party the Greens, which got $3.2 \%$ in the 2017 election; and the Center Party, formerly the farmers' party which got $10.3 \%$ of the vote in the 2017 election. Red, in its party program for 2017-2021 notes that:

Red wants the power back to the people, not to delegations in Brussels and other power centers that negotiate agreements behind our back, against the popular will. The EU's supranational structure and market liberalism are something the people of Europe do not want. Countless popular referenda in EU countries have shown that, now last when the British voted in favor of exiting the EU in June 2016. (Red, 2017, p. 78, authors' translation)

Politically speaking, Red as Norway's most left-wing party is far apart from the UK Tories that are driving
Brexit. The main thrust of Brexit is therefore the Brexit mantra of 'taking back control,' in other words an argument in favor of sovereignty. Beyond that there are no grounds for assuming that the deeply capitalism-critical party Red will want any of the other policies that the UK Tories propound.

The Greens, in the party program for 2017-2021, notes that:

Brexit shows that popular trust in the EU is at a historic low, a result of among other things increased economic differences, fear of consequences of increased immigration and democratic deficit. Together with our European sister parties the Greens will work to reform the EU-system and the EEA Agreement, with more transparency, more democracy, better protection of climate and environment and more participation as the goals. (Greens, 2017 , p. 85, authors' translation)

It is interesting that the Greens not only underline a European cooperation strategy to foster change rather than a national strategy, but also propagate changes that will strengthen the EU.

The Center Party notes in its party program for 2017-2021 that:

The British popular referendum on EU membership has created a completely new dynamics in Europe and will probably create a new opportunity space for alternatives to the EU's goal of an ever closer union. Norway must actively exploit the opportunities that the new situation creates. If it becomes possible, Norway should actively cooperate with Great Britain to create an alternative connection 
to the EU where both market access and national sovereignty are ensured. (Centre Party, 2017, p. 87, authors' translation)

All three parties are on the left-of-center in the Norwegian political landscape. Red is on the far left, Greens is closer to the center. The Center Party is a centrist party that in the last decade has been part of the Labor-led coalition. Red and the Center Party are the two most Eurosceptical parties in Norway, and have been so as long as the issue has existed. All three parties' stances to different degrees advocate changes to Norway's present EU affiliation but in quite different directions. The Center Party and Red see Brexit as opening space for altering Norway's formal EU affiliation, to regain Norwegian sovereignty. The Centre Party depicts Brexit as a great opportunity and actively seeks to politicize Norway's EU affiliation, and as such operates as a political entrepreneur in the sense of the benchmark theory. Finally, all three parties present Brexit as an occasion to question the socioeconomic model that Norway has been subjected to through its EU-affiliation, especially Red, which explicitly associates the EU with market liberalism.

The Socialist Left Party (what is now Sosialistisk Venstreparti and got $6 \%$ of the vote in the 2017 election) has historically speaking been Eurosceptic and wants to replace the EEA Agreement with a less committing trade and cooperation agreement with the EU. It wants more market regulation and democracy. Representatives from the Socialist Left Party presented a Private Members' Bill to Parliament in 2019 bent on initiating a public inquiry on alternatives to the EEA Agreement that would involve a less binding or committing relationship. Party leader Audun Lysbakken argued that the relationship between the EU and non-member countries is changing, and that "the truth is that we still do not know what type of agreement Great Britain and the EU will strike....It will, however, establish a new template for the relationship between the EU and non-member countries" (Lysbakken, 2019, authors' translation). The proposal was turned down by a majority of the parliamentary committee, which argued that it was lopsided and that the benefits of renegotiation were uncertain. Labor (Arbeiderpartiet, which got 27.4\% in the 2017 election) has historically been pro-EU but has also been deeply divided internally (60-40 split in favor of EU membership). Labor underlines the need to retain the EEA Agreement but also expresses reservations about the negative effects on the labor market and workers' rights. The Christian Democrats, historically the party that has been most committed to the EEA Agreement, underlines the need to retain Norway's present EU affiliation. The Christian Democrats maintain that a bilateral trade agreement will not provide the same market access, and that Norway must support binding international and European cooperation to solve Europe's refugee challenge. The Conservative Party (Høyre) which got $25 \%$ of the vote in the 2017 national election and is traditionally the most supportive of EU membership has toned down the support for EU membership and instead underlines the need to retain Norway's current EU affiliation.

Europe's Eurosceptic (or even Europhobe) right-wing populists have uniformly hailed Brexit as a great opportunity to undo the EU's influence. The Progress Party (which got $15.2 \%$ of the vote in the 2017 election) and is Norway's right-wing populist party does not mention Brexit explicitly in any of its party programs. In effect, if we look at the Progress Party's EU stance, it has historically been supportive of the EEA Agreement, and it is only in the last few years that it has come out explicitly against Norwegian EU membership. Its main concerns now are with Schengen and export of social benefits. Both issues are explicitly linked to immigration, but the Progress Party is mainly concerned with limiting nonWestern immigration. This focus on minor changes to Norway's current EU affiliation is not universally shared. There are some maverick politicians in the party that cast Brexit as an opportunity for a major reshuffling of Norway's external relations: Tybring-Gjedde, who sits on the European Affairs Committee, has argued that Norway could come together with the UK, US, Iceland and Canada to form a trade alliance exceeding the EU in size (Tybring-Gjedde, 2019).

This brief overview has shown that the great majority of Norwegian political parties with a significant majority of the electorate behind them (figures similar to what the polls yielded), support the status quo with only minor changes. What puts Norway apart from much of Europe is that the right-wing populist party is far less Eurosceptic than its sister parties across Northern Europe.

\subsubsection{Social Movements and Interest Groups}

The single most important social movement focusing explicitly on Norway's EU affiliation is the No to the EU organization that at present has around 20,000 members nationwide. It plays a central role as a watchdog, and has shown a tremendous ability to mobilize political opposition to EU membership in the run-up to both EU referendums. In 1994, Nei til EU (No to the EU) had 138,426 members (Bjørklund, 2005, p. 82). In contrast, the yes side had at its most 35,000 members. No to the EU presented a report in 2017 on Brexit's importance for Norway and saw it as a major spur to changing the status quo, not by Norway copying the British agreement but by creating a new situation:

[Brexit] entails new opportunities for Norway that must be seized. The clear goal of the British is a new agreement with the EU that ensures that they regain control of their own laws. The British could trigger calls [the original Norwegian text uses 'be a wall-breaker'] for a new Norwegian solution based on the same principles....Norway ought also 
to negotiate a new agreement with the EU which is without the unilateralism and supranationality of the EEA Agreement. This can take place through a bilateral agreement with the EU or through a regional EFTA-EU agreement where also Switzerland and Great Britain take part. (No to the EU, 2017, p. 48, authors' translation, authors' emphasis)

No to the EU's main focus is sovereignty; there is no mention of the UK's preferred socioeconomic model post-Brexit.

There are also employers' and employees' organizations, which have substantial agenda-setting powers in Norway on matters relating to the EU and EEA (Official Norwegian Reports, 2012, p. 276). The two most central organizations, representing labor and private enterprise respectively, are the Norwegian Confederation of Trade Unions and the Confederation of Norwegian Enterprise. They have historically been, and still are, supportive of the EEA Agreement; the privileged access to the internal market it provides and the association it has to economic stability and growth.

While both the Norwegian Confederation of Trade Unions and the Confederation of Norwegian Enterprise support the EEA Agreement, their views have at times differed strongly. For the Unions, the agreement is controversial for how it challenges the Norwegian socioeconomic model by prompting privatization, deregulation of the labor market and the influx of posted workers facilitated by the EEA and the Schengen Agreement. In 2018, the Confederation of Norwegian Enterprise and the Federation of Norwegian Industries brought an appeal to the European Surveillance Authority after a case against the Norwegian Tariff Committee related to the mandatory reimbursement of posted worker's travel costs had been lost on the part of the employer's organization in the Supreme Court. The fact that representatives of private enterprise brought a case already settled by Norway's Supreme Court to a supranational body for it to be overruled in the disfavor of labor interests caused outrage among the unions. Hans-Christian Gabrielsen, head of the Norwegian Confederation of Trade Unions, accused the employer's organization of "placing a bomb underneath the EEA" (Haugan, 2018). Cases like this have led to mounting criticism of the EEA Agreement among labor union fractions. It culminated in 2019 when a subsidiary organization of the Norwegian Confederation of Trade Unions, The United Federation of Trade Unions' put forward a proposition at their General Assembly that would change its stance on the EEA Agreement from positive to negative. This could have had ramifications on the Norwegian Confederation of Trade Unions' position as well, and in turn put political pressure on the EEA positive left leaning parties in parliament.

Given that the principal argument for Brexit in Great Britain was regaining national regulatory and judicial autonomy, Brexit could easily have functioned as a benchmark for labor unions who were displeased with the prevalence of EU regulations and EU law in Norway. Interestingly, the opposite seems to be the case. At the above mentioned 2019 General Assembly, The Federation of Trade Unions (2019, p. 10) stated that: "The Brexit process in Great Britain demonstrates that it is hardly a realistic alternative to renegotiate the core tenets of the EEA Agreement." This speaks to the fact that many of the political forces in Norway that are critical of the EEA and thus among those most likely to regard Brexit as a benchmark, do not actually see Brexit as a benchmark for future Norway-EU relations.

To sum up thus far, the employer's and employee's organizations have not altered their views on Norway's relationship with the EU as a result of Brexit. Similar to pro-EEA political parties, the employer's organizations continue to support the EEA Agreement because it assures continued economic stability. The employees' organizations, on the other hand, have a much more ambivalent view of the EEA, and to an extent share the Brexit movement's aim of restoring sovereignty.

\section{Conclusion}

This article assessed whether Brexit has spurred a reassessment of Norway's EU relationship, and the implications for the EU's relations with affiliated nonmembers. The analysis shows that the assumptions we derived from the benchmark theory were mostly confirmed. The government and the major political parties saw Brexit as a challenge to a depoliticized status quo that they sought to protect. That included rejecting proposals for studies to explore the effects of less binding alternative affiliations than the EEA Agreement. The preference for the status quo is aligned with public opinion. Some political entrepreneurs sought to change the status quo but did not agree on what they wanted to change: renegotiate the EEA Agreement; renegotiate Schengen; or sign a less comprehensive trade agreement. There was little appetite for a new EU membership debate. Some political entrepreneurs stressed sovereignty, but they generally diverged from the UK's preferred socioeconomic model. Others expressed concern about the EU's neoliberal turn and the problem of social dumping associated with labor mobility. But whereas this stance appears to dovetail with the Brexiteers' onus on regulating immigration, it was not the immigration-critical, right-wing populist Progress Party that was most eager to change the status quo, but parties on the far left. The change-oriented Norwegian political entrepreneurs endorsed a socioeconomic model that was much further to the left than are the UK Conservatives (even those in favor of state aid). An important reason for the lack of explicit reference to the UK as a benchmark on the socioeconomic dimension is precisely this significant discrepancy in understandings of solidarity and economic justice.

With regard to the implications that we can discern for the EU's relations with affiliated non-members, Brexit 
thus far works more as a deterrent, than as an inducement for change. Whether this is mainly due to the tangled Brexit process or whether it is due to the fact that, at least for Norway, Brexit left little scope for linking sovereignty to the socioeconomic problems that actors associate with the present EU affiliation requires further investigation. Note that formerly EU-supportive social democrats largely share these socioeconomic concerns. In the Brexit negotiations, concerns with social justice and environmental standards figured strongly in the EU's demands to the UK, but this does not appear to increase Norwegians' support for EU membership.

Our analysis shows that we cannot assess Brexit as a benchmark without paying attention to the sheer size and magnitude of the EU-Norway power asymmetry. That affects the actors' assessments: risk and uncertainty figure prominently and bring up the question of whether the EU should be more accommodating in its relations with non-members. In that context, from the EU's perspective, the distinction between those that qualify for EU membership and those that do not probably matters. The EU has proven exceptionally inclusive with regard to non-members that qualify for EU membership (the EFTA states) - provided they abide by EU laws and regulations. But there are limits. If the EU is very accommodating to states that qualify for membership but refuse to seek it, the EU risks lowering the bar for exit or pleas to renegotiate the terms of membership from its member states. In that sense Brexit may expose the special arrangements that EFTA states have with the EU.

These considerations remind us that the $\mathrm{EU}$ as a non-state entity is particularly disposed to import centrifugal pressures from how it structures its affiliations with non-members.

\section{Acknowledgments}

The authors are grateful for comments and suggestions from Chris Lord, Jarle Trondal, three reviewers and the Academic Editors of the thematic issue.

\section{Conflict of Interests}

The authors declare no conflict of interests.

\section{References}

Bjørklund, T. (2005). Hundre år med folkeavstemninger: Norge og Norden 1905-2005 [Hundred years of popular referendums: Norway and the Nordics 1905-2005]. Oslo: Universitetsforlaget.

Børde, K. (1997). The European Economic Area, Norway and the European Union. In P. C. Müller-Graff \& E. Selvig (Eds.), The European Economic Area: Norway's basic status in the legal construction of Europe (pp. 97-129). Berlin: Berlin Verlag Arno Spitz.

Centre Party. (2017). Senterpartiets program 2017-2021

[The Centre Party's program 2017-2021]. Centre
Party. Retrieved from https://www.senterpartiet. no/Om\%20SP/arkivert/valg-2017/senterpartietsprogram-2017-2021

De Vries, C. E. (2017). Benchmarking Brexit: How the British decision to leave shapes EU public opinion. Journal of Common Market Studies, 55(S1), 38-53.

De Vries, C. E. (2018). Eurosceptisism and the future of European Integration. Oxford: Oxford University Press.

EFTA. (2017). The basic features of the EEA Agreement. EFTA. Retrieved from www.efta.int/eea/eeaagreement/eea-basic-features\#1

Egeberg, M., \& Trondal, J. (1999). Differentiated integration in Europe: The case of the EEA country. Norway. Journal of Common Market Studies, 37(1), 133-142.

Eriksen, E. O., \& Fossum, J. E. (Eds.). (2015). The European Union's non-members: Independence under hegemony? London: Routledge.

European Commission. (2017). Speech by Michel Barnier at the Centre for European Reform on "The Future of the EU." European Commission. Retrieved from https://ec.europa.eu/commission/presscorner/ detail/en/SPEECH_17_4765

Fossum, J. E. (2019). Norway and the European Union. Oxford Research Encyclopedia. Retrieved from https://oxfordre.com/politics/view/10.1093/ acrefore/9780190228637.001.0001/acrefore9780190228637-e-1043

Fossum, J. E., \& Graver, H. P. (2018). Squaring the circle on Brexit: Could the Norway model work? Bristol: Bristol University Press.

Gänzle, S., \& Henökl, T. (2017). From "awkward partner" to "awkward partnership"? Explaining Norway's paradoxical relations with the European Union. In M. Stegmann McCallion \& A. Brianson. (Eds.), Nordic states and European Integration: Awkward partners in the North? (pp. 79-102). London: Palgrave MacMillan.

Greens. (2017). Ta vare på fremtida: Arbeidsprogram 2017-2021 [Take care of the future: Work programme 2017-2021]. Greens. Retrieved from https://d3n8a8pro7vhmx.cloudfront.net/mdg/ pages/309/attachments/original/1548161094/ Arbeidsprogram-2018.pdf?1548161094

Gstöhl, S., \& Phinnemore, D. (Eds.). (2019). The proliferation of privileged partnerships between the European Union and its neighbours. Abingdon: Routledge.

Haugan, B. (2018, November 16). The LO-sjefen: NHO har plassert en bombe under EØS-avtalen [The LO leader: NHO has placed a bomb underneath the EEA Agreement]. VG. Retrieved from https://www.vg.no/ nyheter/innenriks/i/LORMO1/lo-sjefen-nho-harplassert-en-bombe-under-eoes-avtalen

Haugevik, K. (2017). Hva betyr brexit for utenforlandet Norge? [What does Brexit mean for the outsider Norway?]. Internasjonal Politikk, 75(2), 152-166.

Jones, S. (2020, September 27). Swiss voters reject nationalist proposal to curb immigration. Financial 
Times. Retrieved from https://www.ft.com/content/ 5a642ce6-1a76-460c-9857-b880b0fb7bc0

Laffan, B. (2020, September 30). Yves Mény annual lecture [Video file]. Retrieved from https://www. youtube.com/watch?v=hhHXCiOSd0I\&feature= youtu.be

Leuffen, D., Rittberger, B., \& Schimmelfennig, F. (2013). Differentiated integration: Explaining variation in the European Union. London: Palgrave Macmillan.

Lord, C. (2015). The United Kingdom, a once and future (?) non-member state. In E. O. Eriksen \& J. E. Fossum (Eds.), The European Union's non-members: Independence under hegemony? (pp. 211-229). London: Routledge.

Lysbakken, A. (2019, April 11). Innstilling fra utenriks: og forsvarskomiteen om Representantforslag fra stortingsrepresentantene Audun Lysbakken, Solfrid Lerbrekk og Arne Nævra om å utrede alternativer til EØS-avtalen (Innst. 214 S (2018-2019), jf. Dokument 8:58 S (2018-2019)) [Recommendation from the Foreign Affairs and Defence Committee on proposals from the Parliament Representatives Audun Lysbakken, Solfrid Lerbrekk og Arne Nævra on inquiring into alternatives to the EEA Agreement (Inst.214 S (2018-2019). jf. Document 8:58 S (2018-2019))]. Stortinget. Retrieved from https://www.stortinget. no/no/Saker-og-publikasjoner/Publikasjoner/ Referater/Stortinget/2018-2019/refs-201819-04$11 /$ ? $\mathrm{m}=4$

No to the EU. (2017). EØS-meldingen: 25 År med EØS: Konsekvenser for Arbeidsliv og Samfunn [The EEA report: 25 Years with the EEA: Consequences for the labor market and society]. Oslo: No to the EU. Retrieved from https://neitileu.no/aktuelt/eosmeldingen-25-ar-med-eos/E\%C3\%98S-meldingen2017.pdf/_/attachment/inline/aa9d8e39-024b4e2b-ab8b-e682ac0b18e8:a1d681772d395591f 4735a80792a9b901651ca54/E\%C3\%98S-meldingen2017.pdf

Norwegian Government. (2016). Norges handelspolitisk forhold til Storbritannia etter brexit [Norway's trade relations with Great Britain after Brexit]. Oslo:
Norwegian Government. Retrieved from https:// www.regjeringen.no/globalassets/departementene/ ud/vedlegg/europapolitikk/brexit_analyse.pdf

Official Norwegian Reports. (2012). Utenfor og innefor: Norges avtaler med EU [Outside and Inside: Norway's Agreements with the European Union]. Official Norwegian Reports. Retrieved from www.regjeringen. no/no/dokumenter/nou-2012-2/id669368

Red. (2017). Rødts arbeidsprogram: 2017-2021 [Red's work program: 2017-2021]. Red. Retrieved from https://roedt.no/arbeidsprogram

Sentio. (2020). EU and EEA Barometer Timeline [Data set].

Søreide, I. M. E. (2018a). Møte i Europautvalget den 7. februar 2018 [Meeting in the Euroepan Affairs Committee 7 February 2018]. Stortinget. Retrieved from https://www.stortinget.no/no/Saker-ogpublikasjoner/Publikasjoner/Referater/ Europautvalget/2017-2018/refe-201718-02-07/ ?all=true

Søreide, I. M. E. (2018b). Møte i Europautvalget [Meeting in the European Affairs Committee]. Stortinget. Retrieved from https://www.stortinget.no/no/ Saker-og-publikasjoner/Publikasjoner/Referater/ Europautvalget/2017-2018/refe-201718-0920/?all=true

Statistics Norway. (1995). The 1994 Referendum on Norwegian Membership of the EU. Oslo: Statistics Norway. Retrieved from https://www.ssb.no/a/histstat/ nos/nos_c235.pdf

The Federation of Trade Unions. (2019). Norges Tilknytning til EU/EØS [Norway's affiliation with the EU/EEA]. Oslo: The Federation of Trade Unions. Retrieved from https://www.fellesforbundet.no/ globalassets/internasjonalt/eu-eos/uttalelse-omeu-eos-fellesforbundets-landsmote-2019.pdf

Tybring-Gjedde, C. (2019). Møte i Europautvalget [Meeting in the European Affairs Committee]. Stortinget. Retrieved from https://d3n8a8pro7vhmx. cloudfront.net/mdg/pages/309/attachments/ original/1548161094/Arbeidsprogram-2018.pdf? 1548161094

\section{About the Authors}
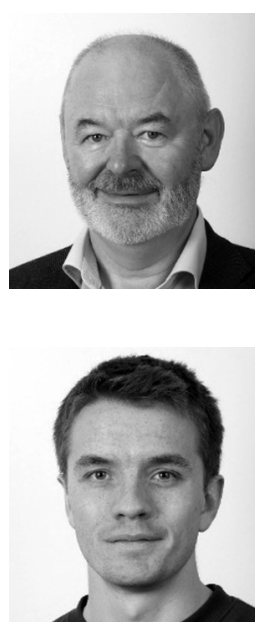

John Erik Fossum is a Professor of Political Science at ARENA Centre for European Studies at the University of Oslo, Norway. He is Project Coordinator of the H2020-project "Differentiation, Dominance and Democracy (EU3D)." His research focuses on issues of polity formation and change, democracy, constitutionalism, and federalism in the EU and Canada.

Oigrestad is Research Assistant at ARENA Centre for European Studies at the University of Techno at ARENA and has carried out research on EU trade agreements. 